\title{
Bioenergetic Pattern of Isolated Type II Pneumocytes in Air and during Hypoxia
}

\author{
L. M. Simon, Department of Medicine, Stanford University School of Medicine, \\ and the Palo Alto Veterans Administration Hospital, Stanford, California 94305 \\ E. D. Robin, T. RAFFin, and J. Theodore, Department of Medicine, Stanford \\ University School of Medicine, Stanford, California 94305 \\ W. H. J. Douglas, W. Alton Jones Cell Science Center, Lake Placid, New York 12946
}

A B S T R A C T The bioenergetic pattern of a cell clone derived from rat lung with ultrastructural and biochemical characteristics like those of type II pneumocytes (T-II-P), has been studied in a tissue culture system. During air cultivation, these cells have a high rate of aerobic and anaerobic glycolysis associated with high activities of two rate-limiting enzymes in glycolysis (pyruvate kinase [PyKi] and phosphofructokinase [PFK]). This is present despite the rates of oxygen consumption and activities of cytochrome oxidase $(\mathrm{CyOx})$ similar to other lung cells. Presumably the high rate of aerobic glycolysis explains the substantial lactate production previously described in lung slices and in the intact perfused lung.

Hypoxic cultivation results in a decrease in $\mathrm{CyOx}$. Acute re-exposure to air does not restore the oxygen consumption to normal, presumably as a result of decreased mitochondrial $\mathrm{O}_{2}$ utilization associated with decreased $\mathrm{CyOx}$ activity. As a result, hypoxically cultivated T-II-P cells have a decreased capacity for mitochondrial ATP generation in air as compared to air-cultivated cells. During hypoxia, aerobic and anaerobic glycolysis are further increased as well as the activities of PyKi and PFK.

The high rate of glycolysis and high activities of PyKi and PFK in cultivated T-II-P appear to reflect intrinsic genetic regulation. The decreased $\mathrm{CyOx}$ activity and increased PyKi and PFK activities in hypoxic T-II-P appear to reflect alterations in enzyme biosynthesis/biodegradation regulated by $\mathrm{O}_{2}$ availability.

Received for publication 28 July 1977 and in revised form 19 December 1977.

\section{INTRODUCTION}

Type II pneumocytes (T-II-P) ${ }^{1}$ play a critical role in alveolar function. it is generally accepted that these cells are the site of synthesis and storage of surface active material in the lung $(1,2)$. In addition, recent work suggests that these cells have an important repair function and may replace type I pneumocytes in several forms of alveolar injury $(3,4)$.

Cell function is dependent on metabolic energy provision and therefore, the metabolic characteristics of this cell type are of interest. Furthermore, metabolic alterations in T-II-P in response to decreased $\mathrm{O}_{2}$ availability may be an important determinant of alveolar function in disease states associated with alveolar hypoxia.

Until recently, precise characterization of the metabolic functions of this cell type has not been possible. This has resulted from inability to obtain pure cell preparations which are sufficiently normal to examine metabolic parameters. The use of cell cloning as described by Douglas and Kaign (5) has provided such a preparation. In the present study, a cloned, T-II-P epithelial cell preparation obtained from rats has been used to examine the energy metabolism of these cells during maintenance in air and under conditions of chronic hypoxia.

Hypoxic exposure results in decreased rates of oxygen utilization associated with decreased activities of a key mitochondrial enzyme, cytochrome oxidase (CyOx).

\footnotetext{
${ }^{1}$ Abbreviations used in this paper: $\mathrm{CyOx}$, cytochrome oxidase; F12-10\% FCS, Hams F12 tissue culture medium (pH = 7.4) supplemented with $10 \%$ fetal calf serum; PFK, phosphofructokinase; PyKi, pyruvate kinase; $\mathrm{QO}_{2}$, oxygen consumption; T-II-P, type II pneumocytes.
} 
The data show that T-II-P possess a high rate of aerobic and anaerobic glycolysis associated with high activities of two rate-limiting glycolytic enzymes, pyruvate kinase $(\mathrm{PyKi})$ and phosphofructokinase (PFK). The exposure of these cells to hypoxic conditions results in the augmentation of the rates of aerobic and anaerobic glycolysis as well as further increases in the activities of the glycolytic enzymes. This bioenergetic adaptation thus provides a possible mechanism for maintenance of cell viability when mitochondrial energy provision is decreased under conditions of alveolar hypoxia.

\section{METHODS}

Cell preparation. Cloned type II pneumocytes were prepared as previously described (5). Cell monolayers were initially maintained in T-150 tissue culture flasks (Corning Medical, Corning Glass Works, Medfield, Mass.) at $37^{\circ} \mathrm{C}$ in $95 \%$ air-5\% $\mathrm{CO}_{2}$. The incubating media used initially, and at all subsequent cultivation times, was Hams F12 tissue culture medium $(\mathrm{pH}=7.4)$ supplemented with $10 \%$ fetal calf serum (F12-10\% FCS). For subculture, the cell monolayers were suspended in F12-10\% FCS and $1 \mathrm{ml}$ of cell suspension containing $50-100,000$ cells was placed in T-75 culture flasks to which $24 \mathrm{ml}$ of F12-10\% FCS was added. The flasks were then incubated in $95 \%$ air-5\% $\mathrm{CO}_{2}$ until confluence. In preliminary experiments, it was determined that this population density (50-100,000 cells/T-75 flask) resulted in confluent cell culture flasks after $\cong 7$ days of in vitro maintenance.

At the time of confluence, two T-75 flasks were harvested (as described below) for either metabolic or enzymatic studies. The T-II-P harvested at confluence were considered the control cells, Enzymatic and metabolic data obtained at this time are referred to as time zero values.

The remaining cell monolayers were refed with $25 \mathrm{ml}$ F12-10\% FCS and incubated in stoppered T-75 flasks under either aerobic $\left(\mathrm{PO}_{2} \sim 140\right.$ torr $)$ or hypoxic $\left(\mathrm{PO}_{2} \sim 15\right.$ torr $)$ conditions for an additional 48-96 h. All cultures were refed and regassed at 24 and $72 \mathrm{~h}$.

Hypoxia was achieved by gassing culture flasks with $95 \%$ nitrogen-5\% $\mathrm{CO}_{2}$. Multiple measurements of media $\mathrm{PO}_{2}$ in the hypoxic flasks (Corning $165 \mathrm{pH} / \mathrm{Blood}$ Gas Analyzer, Corning Medical, Corning Glassworks) indicated that the $\mathrm{PO}_{2}$ was maintained at values of $\sim 15$ torr throughout the 96-h cultivation period. Aerobic conditions were achieved by gassing with $95 \%$ air-5\% $\mathrm{CO}_{2}$. Multiple measurements of media $\mathrm{PO}_{2}$ in the aerobic flasks confirmed that the $\mathrm{PO}_{2}$ was maintained at $\sim 140$ torr. Media $\mathrm{pH}$ was measured (Corning $165 \mathrm{pH} /$ Blood Gas Analyzer) at the different cultivation times and no significant differences between the aerobic and hypoxic systems were noted.

Flasks were harvested at 48 and $96 \mathrm{~h}$ for either metabolic or enzymatic studies. In addition, identically prepared culture systems were processed as described (5) for ultrastructural confirmation of cell types.

\section{Enzyme studies}

Cell preparation. At the time of harvest (48 and $96 \mathrm{~h}$ ), the medium was removed and monolayers incubated in 3.5 $\mathrm{ml}$ of a dispersal medium (collagenase-trypsin-chicken serum) for 10-15 min. Cell dispersal was verified by direct observation and $6.5 \mathrm{ml}$ of $\mathrm{F} 12-10 \%$ FCS added to inactivate proteolytic enzymes. The monolayers were then harvested by a rubber policeman as a $10-\mathrm{ml}$ suspension and an aliquot of this suspension was used for quantitation of cell number. The harvested cells were centrifuged at $700 \mathrm{~g}$ for $10 \mathrm{~min}$ $\left(2-4^{\circ} \mathrm{C}\right)$, washed twice with phosphate-buffered saline $(\mathrm{pH}$ =7.4), suspended in $1.2 \mathrm{ml}, 35 \mathrm{mM}$ tris buffer $(\mathrm{pH}=7.4)$, and disrupted by sonication (Heat Systems-Ultrasonics, Inc. Plainview, N. Y.) for $30 \mathrm{~s}$ at a power output of $70 \mathrm{~W}$. PyKi, $\mathrm{PFK}, \mathrm{CyOx}$, and protein analyses were performed on these cell sonicates.

\section{Enzyme assay}

PyKi activity was assayed by a modification of the spectrophotometric method of Valentine and Tanaka (6). A $0.05-\mathrm{ml}$ sample of cell sonicate was added to a $2.95-\mathrm{ml}$ reaction mixture containing: $0.5 \mathrm{ml}$ of $50 \mathrm{mM}$ triethanolamine- $\mathrm{HCl}$ buffer $(\mathrm{pH}$ $=7.5), 1.45 \mathrm{ml}$ of distilled water, $0.1 \mathrm{ml}$ of $2.25 \mathrm{M} \mathrm{KCl}, 0.1$ $\mathrm{ml}$ of $240 \mathrm{mM} \mathrm{MgSO}, 0.2 \mathrm{ml}$ of $6 \mathrm{mM}$ ADP, $0.1 \mathrm{ml}$ of lactate dehydrogenase ( 18 enzyme units), $0.4 \mathrm{ml}$ of $1.3 \mathrm{mM}$ NADH, and $0.1 \mathrm{ml}$ of $45 \mathrm{mM}$ phosphoenolpyruvic acid (trisodium salt). NADH oxidation at $25^{\circ} \mathrm{C}$ was followed by measuring the decrease in optical density at $340 \mathrm{~nm}$ in a model DB spectrophotometer (Beckman Instruments, Inc., Fullerton, Calif.). Enzyme activity was calculated during a period of zero order kinetics using a molar extinction coefficient of $6.2 \times 10^{3}$ for NADH. Enzyme activity was expressed both as units (micromoles of phosphoenolpyruvate converted to pyruvate per minute) per milligram of cell protein and as units per $10^{6}$ cells.

$\mathrm{CyOx}$ was measured spectrophotometrically by techniques described (7). A 0.1-ml sample of cell sonicate was added to $2.9 \mathrm{ml}$ of reaction mixture containing: $0.3 \mathrm{ml}$ of $10 \%$ sodium deoxycholate, $2.5 \mathrm{ml}$ of $13 \mathrm{mM}$ phosphate buffer ( $\mathrm{pH}=7.4$ ), and $0.1 \mathrm{ml}$ of $3 \%$ solution of cytochrome $c$ (reduced by sodium hydrosulfite). Oxidation of cytochrome $c$ at $25^{\circ} \mathrm{C}$ was followed by measuring the decrease in optical density at $550 \mathrm{~nm}$ in a model DB spectrophotometer. Enzyme activity was calculated using a molar extinction coefficient of $19.1 \times 10^{3}$ for cytochrome $c$ and units expressed as micromoles cytochrome $c$ oxidized per minute per milligram of protein and per $10^{6}$ cells.

PFK was assayed spectrophotometrically by following the conversion of fructose-6-phosphate to fructose-1,6-diphosphate (8). A $0.1-\mathrm{ml}$ sample of cell sonicate was added to a reaction mixture containing $1.735 \mathrm{ml}$ of $0.1 \mathrm{M}$ Tris- $\mathrm{HCl}, \mathrm{pH} 8.2$, $0.05 \mathrm{ml}$ of $0.1 \mathrm{M} \mathrm{MgCl}, 0.2 \mathrm{ml}$ of $0.1 \mathrm{M} \mathrm{Na}_{2} \mathrm{PO}_{4}, 0.175 \mathrm{ml}$ "enzyme mix", $0.56 \mathrm{ml}$ of "substrate mix", and $0.27 \mathrm{ml} \mathrm{NADH}$ $(1.4 \mu \mathrm{mol} / \mathrm{ml}$ ). (Enzyme mix: $4.92 \mathrm{ml}$ of $0.1 \mathrm{M}$ Tris- $\mathrm{HCl}$, $\mathrm{pH}=8.2,0.6 \mathrm{ml}$ aldolase $[10 \mathrm{mg} / \mathrm{ml}])$. (Substrate mix: $0.1 \mathrm{M}$ fructose-6-phosphate; 0.1-M ATP).

NADH oxidation was followed spectrophotometrically at $25^{\circ} \mathrm{C}$ and enzyme activity calculated during a period of zero order kinetics. Enzyme activity was expressed both as units (micromoles of fructose-6-phosphate converted to fructose1,6-biphosphate per minute) per milligram of protein and as units per $10^{6}$ cells.

\section{Aerobic and anaerobic lactate production}

Fresh media (F12-30\% FCS, $10 \mathrm{mM}$ glucose, $\mathrm{pH}=7.4$ ) was added to T-75 flasks at the time of study, and paired stoppered flasks were incubated under aerobic (95\% air$\left.5 \% \mathrm{CO}_{2}\right)$ or anaerobic $\left(95 \% \mathrm{~N}_{2}-5 \% \mathrm{CO}_{2}\right)$ conditions for 150 min, at $37^{\circ} \mathrm{C}$. Aliquots $(0.5 \mathrm{ml})$ of incubating media were removed from the flasks after 30,90 , and $150 \mathrm{~min}$ of incubation and immediately added to an equal volume of chilled 
$3.5 \%$ perchloric acid. Lactate production was relatively linear over this time period and the change in lactate concentration from 30 to $150 \mathrm{~min}$ was used to calculate the rate of lactate production. The deproteinized samples were centrifuged at $1,000 \mathrm{~g}$ and the resultant supernate was used for lactate analyses (9). The cell monolayers were then harvested for cell counting and the final cell pellet was suspended in $1.2 \mathrm{ml}$ of $35 \mathrm{mM}$ Tris. Protein determinations were performed on this cell suspension and lactate production expressed as micromoles lactate produced per hour per milligram protein and per $10^{6}$ cells.

\section{Oxygen consumption}

T-II-P were harvested and counted, washed twice with $\mathrm{F} 12$, and the cell pellets were suspended in $8 \mathrm{ml}$ of $\mathrm{F} 12$ $(\mathrm{pH}=7.4) .4-\mathrm{ml}$ aliquots of this cell suspension were used to measure $\mathrm{O}_{2}$ consumption in the YSI $53 \mathrm{O}_{2}$ monitor (Yellow Springs Instrument Co., Yellow Springs, Ohio). The cell suspension was equilibrated with room air $\left(\mathrm{PO}_{2} \sim 150\right)$ before measurement and the decrease in $\mathrm{O}_{2}$ concentration was then determined over a 15 -min time period; the $\mathrm{O}_{2}$ consumption was linear over this time period. Total cell protein of these aliquots were determined and the $\dot{Q} \mathrm{O}_{2}$ expressed as micromoles oxygen consumed per hour per milligram protein and per $10^{6}$ cells.

\section{Protein analysis}

Protein content was determined by the method of Lowry et al. (10) using crystalline human albumin as the standard.

\section{Cell quantitation}

Cell counts were performed in standard fashion using a hemocytometer. Cell viability was assessed using Trypan blue and was $>95 \%$ at all times.

\section{Fibroblast studies}

To examine the specificity of the bioenergetic properties demonstrated in T-II-P, a separate series of studies was carried out using cultivated rat lung fibroblasts. Rat lung fibroblasts were obtained using a modification of the method of Balin et al. (11). Whole rat lungs were dissociated (using a collagenase-trypsin-chicken serum medium) into single viable cells. The resulting cell suspension was innoculated into T-75 culture flasks at $d 5 \times 10^{5}$ cells/T-75 flasks (F12$10 \% \mathrm{FCS}, 37^{\circ} \mathrm{C}, 95 \%$ air $-5 \% \mathrm{CO}_{2}$ ) and maintained to semiconfluency. Serial passage (three times) of these primary cultures at relatively high density $\left(5 \times 10^{5}\right.$ cells/T-75 flask) was then carried out. Under these conditions, fibroblasts replicate rapidly and become the dominant cell type.

The cell populations obtained by this technique have the morphologic characteristics of fibroblasts on light microscopy and demonstrate polymerized collagen between cells on electron microscopy. No lamellar bodies or surfactant associated markers are demonstrable.

In the present studies, the isolated fibroblasts were used to prepare confluent monolayers in $T-75$ culture flasks ( $\mathrm{F} 12-10 \% \mathrm{FCS}, 37^{\circ} \mathrm{C}, 95 \%$ air- $5 \% \mathrm{CO}_{2}$ ) and cells processed for metabolic and enzyme studies as described above.

\section{RESULTS}

Table I summarizes data with respect to $\mathrm{O}_{2}$ consumption and $\mathrm{CyOx}$ activity in control (confluent) cells and in cells cultivated up to $96 \mathrm{~h}$ in air and in a hypoxic environment. After confluence (time zero), T-II-P cultivated in air show a significant increase in total $\mathrm{QO}_{2}$. The $\mathrm{QO}_{2}$ per $10^{6}$ cells increases by $\sim 75 \%$ during the $96 \mathrm{~h}$ of aerobic cultivation (from $0.15 \pm 0.03$ to 0.26 $\pm 0.07 \mu \mathrm{m}[P<0.01])$. [The $\dot{Q}_{2}$ per milligram protein increases by $\sim 50 \%$ during this period. The change in $\mathrm{QO}_{2}$ per milligram protein is less than the change per $10^{6}$ cells because of a relative increase in cell protein during the period of cultivation. As with $\mathrm{QO}_{2}$, changes in glycolysis and enzyme activity per $10^{6}$ cells were not quantitatively identical with changes per milligram protein because of increases in cell protein during cultivation. To establish that observed alterations do not merely reflect variable changes in cell protein or cell number under the different culture conditions, all data is expressed both per milligram protein and per $10^{6}$ cells.]

The changes in $\dot{Q} \mathrm{O}_{2}$ are accompanied by significant

TABLE I

$\mathrm{O}_{2}$ Consumption* and CyOx Activities as Function of Maturation and Hypoxia in Cultivated T-II-P

\begin{tabular}{|c|c|c|c|c|c|c|}
\hline & \multicolumn{3}{|c|}{ Aerobic cultivation $\mathrm{PO}_{2} \sim 140$} & \multicolumn{3}{|c|}{ Hypoxic cultivation $\mathrm{PO}_{2} \sim 15$} \\
\hline & $\mathrm{Oh}$ & $48 \mathrm{~h}$ & $96 \mathrm{~h}$ & o h & $48 \mathrm{~h}$ & $96 \mathrm{~h}$ \\
\hline \multicolumn{7}{|l|}{$\mathrm{O}_{2}$ consumption } \\
\hline$\mu \mathrm{m} / \mathrm{mg}$ protein & $0.52 \pm 0.07$ & $0.69 \pm 0.09$ & $0.70 \pm 0.13$ & $0.52 \pm 0.07$ & $0.32 \pm 0.03 \S$ & $0.23 \pm 0.08 \S$ \\
\hline$\mu \mathrm{m} / 10^{6}$ cells & $0.15 \pm 0.03$ & $0.23 \pm 0.07$ & $0.26 \pm 0.07$ & $0.15 \pm 0.03$ & $0.11 \pm 0.07 \ddagger$ & $0.10 \pm 0.07 \S$ \\
\hline \multicolumn{7}{|l|}{$\mathrm{CyOx}$} \\
\hline $\mathrm{U} / \mathrm{mg}$ protein & $9.2 \pm 1.3$ & $9.6 \pm 1.7$ & $12.4 \pm 1.1$ & $9.2 \pm 1.3$ & $7.8 \pm 1.2^{\prime}$ & $7.1 \pm 1.1 \S$ \\
\hline $\mathrm{U} / 10^{6}$ cells & $3.0 \pm 0.6$ & $4.1 \pm 0.9$ & $5.8 \pm 1.7$ & $3.0 \pm 0.6$ & $3.1 \pm 0.6^{\prime \prime}$ & $3.7 \pm 0.8^{\prime \prime}$ \\
\hline
\end{tabular}

* Micromoles $\mathrm{O}_{2}$ consumed per hour.

$\$$ Mean \pm SD.

$\S P<0.01$ (compared to air-cultivated cells).

" $P<0.05$ (compared to air-cultivated cells).

$n=7$ for all studies. 
increases in CyOx activity at $96 \mathrm{~h}$, measured either per milligram of cell protein (from 9.2 \pm 1.3 to 12.4 $\pm 1.1, P<0.01$ ) or per $10^{6}$ cells (from $3.0 \pm 0.6$ to 5.8 $\pm 1.7, P<0.05$ ).

Confluent T-II-P cells appear to undergo increases in oxygen metabolism similar to those noted during in vitro cultivation in other cell systems such as W1-38 cells (12). Increased respiration is accompanied by parallel increases in $\mathrm{CyOx}$ as is true in a wide variety of cell and organ systems $(7,13)$. Assuming that $\cong 75 \%$ of total $\mathrm{O}_{2}$ consumption reflects mitochondrial $\mathrm{O}_{2}$ uptake, mitochondrial $\mathrm{O}_{2}$ utilization at $96 \mathrm{~h}$ is similar to that in at least one other lung cell studied under identical conditions, the alveolar macrophage (13).

Because of the temporal changes that occur during in vitro maintenance under standard (aerobic) conditions, an assessment of the effect of any variable on metabolic parameters requires time-matched analysis. During hypoxia, total $\mathrm{QO}_{2}$ significantly decreases so that at $96 \mathrm{~h}$, the hypoxic T-II-P reexposed to air used only about one-third of the total $\mathrm{O}_{2}$ consumed by the time-matched air-maintained cells (air-0.70 $\pm 0.13 \mu \mathrm{m} /$ $\mathrm{mg}$ protein; hypoxia- $0.23 \pm 0.08 \mu \mathrm{m}, P<0.01)$. These differences in $\mathrm{QO}_{2}$ are associated with significant differences in $\mathrm{CyOx}$ activities between the air-maintained and hypoxic T-II-P.

In addition, there are absolute decreases in $\mathrm{QO}_{2}$ after hypoxia (time 0-[confluent]-0.52 $\pm 0.07 \mu \mathrm{m} / \mathrm{mg}$ protein; $96 \mathrm{~h}$ hypoxia- $0.23 \pm 0.08 \mu \mathrm{m}, P<0.01)$. This absolute decrease in $\mathrm{QO}_{2}$ suggests that the changes in $\mathrm{O}_{2}$ consumption are not merely an inhibition of development of mitochondrial $\mathrm{O}_{2}$ utilization but reflect a true change in bioenergetic pattern during hypoxia.

Table II summarizes the data concerning glycolytic rates. The rate of aerobic glycolysis is high in the control cells (time 0 ) averaging almost $3 \mu \mathrm{mol}$ lactate $/ \mathrm{mg}$ cell protein per $h$. This is a value which is 10 times as high as aerobic lactate production studied under identical conditions in another lung cell type, the alveolar macrophage, and is three times the value found in peritoneal macrophages (13).

Unlike respiration, there is no significant increase in either aerobic or anaerobic glycolysis (per milligram cell protein) during maturation in air. The ratio of anaerobic to aerobic glycolysis is $\sim 150 \%$ in control cells (time 0 ) and is unchanged after maturation.

In contrast to the data in air-cultivated cells, there is a striking and progressive increase in both aerobic and anaerobic glycolysis after cultivation under hypoxic conditions. Both aerobic and anaerobic lactate production are significantly greater in T-II-P exposed to hypoxia as compared to those maintained in air. In fact, after $96 \mathrm{~h}$ of hypoxic cultivation, the rate of aerobic glycolysis is as high as the rate of anaerobic glycolysis in the air-cultivated cells. The ratio of anaerobic to aerobic glycolysis, however, is similar to that in the air-cultivated cells.

Table III summarizes data with respect to temporal changes in two rate-limiting glycolytic enzymes. The specific activities of both PyKi and PFK are relatively high in control cells, (as compared, for example, to alveolar macrophages [13]), but do not change significantly during air incubation. It appears that one mechanism for the high rates of glycolysis in this cell type are the high activities of rate-limiting glycolytic enzymes.

During hypoxic cultivation, there are dramatic increases in the activities of both PyKi and PFK which parallel the changes in glycolytic capacity. These increases in enzyme activities presumably subserve enhanced glycolytic energy provision under conditions of decreased $\mathrm{O}_{2}$ availability.

The results of the metabolic and enzyme studies carried out on confluent fibroblasts are shown in Table IV. The equivalent T-II-P data is shown for comparison. Rates of aerobic and anaerobic glycolysis are significantly less in the cultivated fibroblast. The lower

TABLE II

Changes in Aerobic and Anaerobic Glycolysis* in T-II-P Maintained Under Aerobic and Hypoxic Conditions

\begin{tabular}{|c|c|c|c|c|c|c|}
\hline & \multicolumn{3}{|c|}{ Aerobic cultivation $\mathrm{PO}_{2} \sim 140$} & \multicolumn{3}{|c|}{ Hypoxic cultivation $\mathrm{PO}_{2} \sim 15$} \\
\hline & $0 \mathrm{~h}$ & $48 \mathrm{~h}$ & $96 \mathrm{~h}$ & $0 \mathrm{~h}$ & $48 \mathrm{~h}$ & $96 \mathrm{~h}$ \\
\hline \multicolumn{7}{|l|}{ Aerobic glycolysis } \\
\hline$\mu \mathrm{m} / \mathrm{mg}$ protein & $2.89 \pm 0.52$ & $2.17 \pm 0.55$ & $2.64 \pm 0.43$ & $2.89 \pm 0.52$ & $3.11 \pm 0.74 \downarrow$ & $3.17 \pm 0.54 \oint$ \\
\hline$\mu \mathrm{m} / 10^{6}$ cells & $1.00 \pm 0.26$ & $0.97 \pm 0.31$ & $1.40 \pm 0.28$ & $1.00 \pm 0.26$ & $1.59 \pm 0.67$ & $2.40 \pm 0.67$ \\
\hline \multicolumn{7}{|c|}{ Anaerobic glycolysis } \\
\hline$\mu \mathrm{m} / \mathrm{mg}$ protein & $3.85 \pm 0.53$ & $3.11 \pm 0.46$ & $3.71 \pm 0.40$ & $3.85 \pm 0.53$ & $4.46 \pm 0.99$ & $4.72 \pm 0.62 \S$ \\
\hline$\mu \mathrm{m} / 10^{6}$ cells & $1.30 \pm 0.21$ & $1.40 \pm 0.23$ & $2.02 \pm 0.52$ & $1.30 \pm 0.21$ & $2.02 \pm 0.44$ & $3.11 \pm 0.41 \S$ \\
\hline
\end{tabular}

* Micromoles of lactate produced per hour.

$\ddagger P<0.05$ (compared to air cultivation).

$\S P<0.01$ (compared to air cultivation).

$n=5$ for all studies. 
TABLE III

Changes in PyKi and PFK Activities in T-II-P Maintained Under Aerobic and Hypoxic Conditions

\begin{tabular}{|c|c|c|c|c|c|c|}
\hline & \multicolumn{3}{|c|}{ Aerobic cultivation $\mathrm{PO}_{2} \sim 140$} & \multicolumn{3}{|c|}{ Hypoxic cultivation $\mathrm{PO}_{2} \sim 15$} \\
\hline & $\mathrm{Oh}$ & $48 \mathrm{~h}$ & $96 \mathrm{~h}$ & $0 \mathrm{~h}$ & $48 \mathrm{~h}$ & $96 \mathrm{~h}$ \\
\hline \multicolumn{7}{|l|}{ PyKi } \\
\hline $\mathrm{U} / \mathrm{mg}$ protein & $316 \pm 62$ & $355 \pm 106$ & $346 \pm 67$ & $316 \pm 62$ & $599 \pm 122^{*}$ & $689 \pm 94$ \\
\hline $\mathrm{U} / 10^{6}$ cells & $122 \pm 37$ & $145 \pm 62$ & $167 \pm 56$ & $122 \pm 37$ & $248 \pm 90^{*}$ & $386 \pm 106^{*}$ \\
\hline \multicolumn{7}{|l|}{ PFK } \\
\hline $\mathrm{U} / \mathrm{mg}$ protein & $29.2 \pm 3.0$ & $36.7 \pm 5.8$ & $35.7 \pm 6.9$ & $29.2 \pm 3.0$ & $64.6 \pm 13.0^{*}$ & $71.8 \pm 13.3$ \\
\hline $\mathrm{U} / 10^{6}$ cells & $9.2 \pm 0.9$ & $14.0 \pm 3.1$ & $16.7 \pm 2.0$ & $9.2 \pm 0.9$ & $26.9 \pm 5.1^{*}$ & $39.2 \pm 5.6 \ddagger$ \\
\hline
\end{tabular}

* $P<0.01$ (compared to air cultivation).

$\$ P<0.001$ (compared to air cultivation).

$n=7$ for all studies.

rates of glycolysis are accompanied by lower activities of $\mathrm{PyKi}$ and PFK. $\mathrm{O}_{2}$ consumption and $\mathrm{CyOx}$ activities are similar in the two cell types.

\section{DISCUSSION}

Studies of isolated lung slices (14) and of the isolated perfused lung $(15,16)$ have shown what appeared to be an anomaly. Despite exposure in situ to relatively high $\mathrm{O}_{2}$ tensions, (alveolar $\mathrm{PO}_{2} \sim 100$ torr) lung slices and intact lung have a substantial rate of lactate production. This finding suggests the existence of a significant population of lung cells with a high rate of aerobic glycolysis. In the present studies, T-II-P are shown to possess high rates of glycolysis despite the fact that these cells normally develop and function at $\mathrm{PO}_{2}$ of $\sim 100$ torr. The rate of aerobic glycolysis in the T-II-P is 30-40 times the rate of aerobic glycolysis found in the isolated perfused lung $(15,16)$ or in tissue slices (14). Differences in the experimental conditions could account for some of this difference. However, the high rates of glycolysis observed in T-II-P suggest that this cell type is, at least in part, responsible for the glycolytic characteristics of intact lung and lung slices.

The validity of this interpretation depends on several assumptions. One is that the cloned cell type used is truly a T-II-P. The evidence for this includes: $(a)$ the light and ultrastructural characteristics of these cells are similar to those of type II cells in situ, particularly with respect to the existence of multiple osmiophilic lamellar bodies, (b) lamellar bodies isolated from these cells resemble those isolated from in situ type II cells in morphologic appearance (5). In addition, three key enzymes in the synthesis of surface active material are present in the cultured cells with activities of choline kinase, cholinephosphate cytidylyltransferase, and cholinephosphotransferase increased as high as 10 -fold, relative to whole lung homogenates (17). Further, there is significant activity of 1-acyl 2-lyso

TABLE IV

Glycolysis, ${ }^{*}$ PyKi, and PFK Activities, $\downarrow \mathrm{O}_{2}$ Consumption, $\$$ and $\mathrm{CyOx}$ Activities $\$$ in Cultivated T-II-P and Fibroblasts at Confluence

\begin{tabular}{|c|c|c|c|c|c|c|}
\hline & \multicolumn{2}{|c|}{ Glycolysis } & \multirow[b]{2}{*}{ PyKi } & \multirow[b]{2}{*}{ PFK } & \multirow[b]{2}{*}{$\mathrm{QO}_{2}$} & \multirow[b]{2}{*}{$\mathrm{CyOx}$} \\
\hline & Aerobic & Anaerobic & & & & \\
\hline \multicolumn{7}{|l|}{ Fibroblast } \\
\hline per $10^{6}$ cells & $0.55 \pm 0.10$ & $0.85 \pm 0.12$ & $52 \pm 15$ & $5.8 \pm 1.3$ & $0.16 \pm 0.02$ & $3.3 \pm 0.7$ \\
\hline per mg protein & $1.69 \pm 0.22$ & $2.69 \pm 0.31$ & $176 \pm 49$ & $20.4 \pm 4.6$ & $0.52 \pm 0.07$ & $12.5 \pm 2.0$ \\
\hline \multicolumn{7}{|l|}{ T-II-P } \\
\hline per $10^{6}$ cells & $1.00 \pm 0.26^{\prime \prime}$ & $1.30 \pm 0.21^{11}$ & $122 \pm 37^{\prime \prime}$ & $9.2 \pm 0.9^{\prime \prime}$ & $0.15 \pm 0.03$ & $3.0 \pm 0.6$ \\
\hline per mg protein & $2.89 \pm 0.52^{\prime \prime}$ & $3.85 \pm 0.53^{\prime \prime}$ & $316 \pm 62^{\prime \prime}$ & $29.3 \pm 3.0$ & $0.52 \pm 0.07$ & $9.2 \pm 1.3$ \\
\hline
\end{tabular}

* Micromoles of lactate produced per hour.

†nzyme units.

$\S$ Micromoles $\mathrm{O}_{2}$ consumed per hour.

" $P<0.01$ (compared to confluent fibroblasts). 
phosphotidylcholine acyl-CoA acyltransferase, ${ }^{2}$ an enzyme involved specifically in the biosynthesis of surface-active material.

In addition to these published observations, the morphologic appearance of the cell populations used in the present studies was specifically confirmed and the cells were shown to have the characteristics expected of differentiated T-II-P. The cells cultivated at $\mathrm{PO}_{2}$ of both $\sim 140$ and $\sim 15$ torr demonstrated osmiophilic lamellar bodies. The hypoxic T-II-P did not appear to show significant changes in either size or number of these characteristic inclusion bodies (18).

Precise characterization of most specialized cell types in tissue culture systems are difficult and some reservations are appropriate (19). The use of the cloning technique does, however, insure that the cell population being studied was homogeneous in nature.

The second assumption is that the metabolic activities of these cells are similar to those found in situ. It is well known that cultured cells may transform in vitro and show evidence of dedifferentiation. Unlike dedifferentiated cells, the present cells maintained normal contact properties assuming a confluent pattern with maturation. After confluence, the cells demonstrate a replication rate that is much less than that demonstrated during the log phase growth. Finally, karyotyping indicates that the cells are diploid. It is therefore probable that the metabolic properties of these cells are not the results of tissue culture transformation.

To further evaluate the validity of the assumption that the metabolic activities demonstrated are relatively specific for T-II-P and are not an artifact of tissue culture, a separate series of studies was carried out using cultured lung fibroblasts. The disparity between the rates of glycolysis in the two cultivated lung cell systems in the face of similar rates of $\mathrm{O}_{2}$ utilization is consistent with the conclusion that the metabolic properties observed in T-II-P reflect a specific property of this cell type rather than a nonspecific property of cultured lung cells.

The rate of aerobic glycolysis in these cells is remarkable. A number of cell types such as cancer cells (Warburg effect), retina, turtle brain, and renal medullary cells $(20-22)$ have been shown to have high rates of aerobic glycolysis. All of these cell types normally exist in a relatively low $\mathrm{O}_{2}$ environment (tissue $\mathrm{PO}_{2} \sim 25$ torr). However, cells in the alveolar wall such as T-II-P, function in an $\mathrm{O}_{2}$-rich environment. On the air side, $\mathrm{PO}_{2}$ values of about 100 torr are present. On the blood side, pulmonary capillary blood is unique (as compared to other capillary beds) in having a rapid increase

\footnotetext{
${ }^{2}$ Frosolono, M. F., and W. H. Douglas. 1977. 1-acyl 2phosphocholine acyl-CoA acyltransferase in cultured type II alveolar epithelial cells derived from rat lung. Manuscript in preparation.
}

(rather then decrease) in $\mathrm{O}_{2}$ tension as blood passes from the (pulmonary) arterial to the (pulmonary) venous end. Thus, a high rate of lactate production is present despite a luxuriant $\mathrm{O}_{2}$ supply.

One possible explanation for the high rates of aerobic glycolysis is that these cells have an unusually low rate of mitochondrial $\mathrm{O}_{2}$ utilization in air. This does not appear to be the case. The high rate of aerobic glycolysis in T-II-P is present despite a rate of total oxygen utilization which is comparable to that previously demonstrated in other tissue culture maintained cells $(23,24)$ and is similar to the rate of $\mathrm{O}_{2}$ utilization in lung fibroblasts from the same species.

Although it is difficult to interpret measurements of $\mathrm{O}_{2}$ consumption in isolated cell systems in an absolute sense (the values observed depend heavily on the conditions of measurement, and are influenced by cell density, conditions of incubation, substrate concentrations, etc.), the data suggest that the ability to derive ATP from glycolysis plays some special role in these cells. The lung is often subjected to variable degrees of alveolar hypoxia as the result of disease. It is well known that even after months of atelectasis, alveoli are capable of being reexpanded with preservation of parenchymal integrity. High rates of glycolytic energy provision could presumably play an important role in maintaining cell viability under these conditions.

The finding that the Pasteur effect is only moderate in control (confluent) cells is of particular interest. This finding has been reported in other cell types with high rates of aerobic glycolysis and indicates that such cell types are functioning close to glycolytic capacity despite normal respiration (24).

During hypoxic cultivation, there is a significant decrease in CyOx activity. When these cells are acutely exposed to air (during the measurement of $\mathrm{QO}_{2}$ ), $\dot{\mathrm{QO}}_{2}$ is strikingly diminished despite a normal $\mathrm{O}_{2}$ supply. This observation has two important implications. It indicates that the decrease in CyOx activity most probably reflects a true change in $\mathrm{CyOx}$ content rather than merely being a result of changes in low molecular weight regulators or cofactors. Despite reexposure to adequate $\mathrm{O}_{2}, \mathrm{QO}_{2}$ remains low as compared to control (time zero) cells studied under identical conditions. This must occur because there has been an intrinsic alteration of mitochondrial $\mathrm{O}_{2}$ utilization. One explanation is that this occurred because of a parallel reduction of $\mathrm{CyOx}$ content. In turn, this suggests that molecular $\mathrm{O}_{2}$ modified the biosynthesis/biodegradation of this enzyme. This type of enzyme regulation has been demonstrated in anaerobic vs. aerobic yeast. In that system, anaerobiosis is associated with the loss of cytochrome oxidase activity (25). Yeast $\mathrm{CyOx}$ can be resolved into six or seven polypeptides, the three largest are formed on mitochondrial ribosomes, whereas the others are made on cytoplasmic ribosomes. In the absence of molecular 
$\mathrm{O}_{2}$, two of the mitochondrial peptides are no longer synthesized. Because $\mathrm{O}_{2}$ is required for the biosynthesis of the complete enzyme, lack of $\mathrm{O}_{2}$ leads to loss of CyOx activity (26).

The precise mechanism for altered CyOx activity in T-II-P (a mammalian system) has not been studied, but it appears likely that molecular $\mathrm{O}_{2}$ does play a role in the long-term regulation of $\mathrm{CyOx}$.

The second implication involves the temporal relations of reductions in CyOx activity and reduced $\mathrm{QO}_{2}$. The former is a process which requires hours to days. It therefore seems probable that restoration to control values would also require substantial periods of time. As a result, when the hypoxic cell is restored to a normal $\mathrm{O}_{2}$ environment it still manifests a profound depression of mitochondrial $\mathrm{O}_{2}$ utilization with a concomittant reduction in capacity for aerobic ATP generation. Thus, the hypoxically mediated decrease in $\mathrm{CyOx}$, which is presumably part of the bioenergetic adaptations subserving more favorable energetics during hypoxia, limits an optimal energy provision when $\mathrm{O}_{2}$ availability is increased.

After hypoxic cultivation, there is a substantial increase in the rate of aerobic and anaerobic glycolysis though the relationship between the two remains unaltered. The hypoxically cultivated T-II-P actually has a rate of aerobic glycolysis which is equal to the rate of anaerobic glycolysis in the air-cultivated cell. The augmentation of glycolysis during chronic hypoxia must play a role in the ability of this cell to survive prolonged $\mathrm{O}_{2}$ depletion.

In considering the basis for the glycolytic properties of these cells, a major finding is the high activities of PyKi and PFK. In the control (time zero) T-II-P, these activities are significantly greater than in the cultivated lung fibroblasts. Glycolytic enzyme activity in these cells is also greater than in both alveolar macrophages cultivated under aerobic conditions (13), and in whole lung homogenates (27). The activities of both PFK and PyKi are important in controlling the rate of glycolysis $(28,29)$. We have shown in a number of systems that PyKi and PFK activities are quantitative markers for glycolytic capacity $(13,27)$. A similar relationship has also been demonstrated in tumor cells (30). Presumably, the high activities of these enzymes are intrinsically programmed in T-II-P because all TII-P cells were only exposed to normal (and not low) $\mathrm{O}_{2}$ tensions before confluence.

The increase in glycolysis during hypoxia is at least partially mediated by a further increase in the activities of the rate-limiting glycolytic enzymes. This increase in PyKi and PFK, under hypoxic conditions, may in turn be related to another more general mechanism. We have shown that changes in energy metabolism enzyme activities (both glycolytic and those of oxidative phosphorylation) are regulated by $\mathrm{O}_{2}$ tension in alveolar and peritoneal macrophages $(13,31)$. The present studies demonstrate the operation of this adaptive mechanism in another cell type.

Enzyme activities rather than enzyme contents were measured. It is possible that the changes in activity with hypoxia could be related to changes in cofactors or low molecular weight regulators of $\mathrm{CyOx}, \mathrm{PyKi}$, and PFK. This seems unlikely since $(a)$ enzyme activities were measured under standard conditions by in vitro assay systems and $(b)$ a series of complex changes would be required which both decreased $\mathrm{CyOx}$ activity and increase PyKi and PFK activity.

If the content of the various enzymes is changed, the altered enzyme activities may be a result of changes in the rate of biosynthesis or biodegradation of these enzymes as modified by $\mathrm{O}_{2}$ availability. Thus, the net ability of this cell to withstand hypoxia seems to stem from a combination of $(a)$ intrinsic metabolic characteristics found specifically in T-II-P upon which may be superimposed $(b)$ bioenergetic alterations produced by a general regulatory mechanism involving alterations of enzyme biosynthesis and(or) biodegradation evoked by differences in $\mathrm{O}_{2}$ availability.

\section{ACKNOWLEDGMENTS}

This work was supported by grant $\mathrm{OH} 00352$ from the National Institute of Occupational Safety and Health, and by grant 7904-01 from the Veterans Administration.

\section{REFERENCES}

1. Bensch, L., K. Schaefer, and M. E. Avery. 1964. Granular pneumocytes; electron microscopic evidence of exocrine function. Science (Wash. D. C.). 145: 1318.

2. Ashkin, F. B., and C. Kuhn. 1971. The cellular origin of pulmonary surfactant. Lab. Invest. 25: 260-268.

3. Adamson, I. Y. R., and D. H. Bowden. 1974. The type II cells as progenitor of alveolar epithelial regeneration. A cytodynamic study in mice after exposure to oxygen. Lab. Invest. 30: 35-42.

4. Bonikos, D. S., K. G. Bensch, S. K. Ludwin, and W. H. Northway, Jr. 1975. Oxygen toxicity in the newborn. The effect of prolonged 100 percent $\mathrm{O}_{2}$ exposure on the lungs of newborn mice. Lab. Invest. 32: 619-635.

5. Douglas, W. H. J., and M. E. Kaighn. 1974. Clonal isolation of differentiated rat lung cells. In Vitro (Rockville). 10: 230-237.

6. Valentine, W. N., and K. R. Tanaka. 1966. Pyruvate kinase: clinical aspects. Methods Enzymol. 9: 468-473.

7. Simon, L. M., and E. D. Robin. 1974. Relationship of cytochrome oxidase activity to vertebrate total and organ oxygen consumption. Int. J. Biochem. 2: 569-573.

8. Mansour, T. E. 1963. Studies on heart phosphofructokinase: purification, inhibition, and activation. J. Biol. Chem. 238: 2285-2292.

9. Scholtz, R. H., Schmitz, T. Bucher, and J. Lampen. 1959. Uber die wirkung von mystatin auf backerhefe. Biochem. J. 33: $71-86$.

10. Lowry, O. H., N. J. Rosebrough, A. L. Farr, and R. J. Randal. 1951. Protein measurement with the Folin phenol reagent. J. Biol. Chem. 193: 265-275. 
11. Balin, A. K., D. B. P. Goodman, J. Rasmussen, and V. J. Cristofalo. 1976. The effect of oxygen tension on the growth and metabolism of W1-38 cells. J. Cell Physiol. 89: $235-250$.

12. Hayflick, L., and P. S. Moorhead. 1961. The serial cultivation of human diploid cell strains. Exp. Cell Res. 25: 585-621.

13. Simon, L. M., E. D. Robin, J. R. Phillips, J. Acevedo, S. G. Axline, and J. Theodore. 1977. Enzymatic basis for bioenergetic differences of alveolar versus peritoneal macrophages and enzyme regulation by molecular $\mathrm{O}_{2}$. J. Clin. Invest. 59: 443-448.

14. Tierney, D. F. 1971. Lactate metabolism in rat lung tissue. Arch. Intern. Med. 127: 858-860.

15. Longmore, W. J., and J. T. Mourning. 1976. Lactate production in isolated perfused rat lung. Am. J. Physiol. 231: $351-354$.

16. Fisher, A. B., H. Steinberg, and D. Bassett. 1974. Energy utilization by the lung. Am. J. Med. 57: 437-446.

17. Douglas, W. H. J., R. W. Teel, R. M. Jones, and P. M. Farrell. 1974. Characterization of a rat lung cell line that can synthesize pulmonary surfactant in vitro. In Vitro (Rockville). 10: 366.

18. Raffin, T. A., L. M. Simon, J. Theodore, W. Douglas, E. D. Robin. 1977. Effects of hypoxia on ultrastructure and superoxide dismutase (SOD) activity in cultured type II pneumocytes (Type II-P). Clin. Res. 26: 137A. (Abstr.)

19. Kaighn, M. E. 1974. Birth of a Culture-Source of postpartum anomalies. J. Natl. Cancer Inst. 53: 1437-1442.

20. Warburg, O. 1956. On the origin of cancer cells. Science (Wash. D. C.). 123: 309-315.

21. Gregg, C. T., J. M. Machinist, and W. D. Currie. 1968. Glycolytic and respiratory properties of intact mammalian cells. Inhibitor studies. Arch. Biochem. Biophys. 127: $101-111$.

22. Robin, E. D. 1973. The evolutionary advantages of being stupid. Perspect. Biol. Med. 16: 359-379.

23. Cristofalo, V. J., and D. Kritchevsky. 1966. Respiration and glycolysis in the human diploid cell strain W1-38. J. Cell. Physiol. 67: 125-132.

24. Gregg, A. T. 1972. Some aspects of the energy metabolism of mammalian cells. In Growth, Nutrition and Metabolism of Cells in Culture. G. H. Rothblatt and V. J. Cristofalo, editors. Ac'ademic Press, Inc. New York. $107-111$.

25. Biggs, D. R., and A. W. Linnane. 1963. The effect of oxygen on the composition and organization of the electron transport system of yeast. Biochem. Biophys. Acta. 78: 785-788.

26. Mason, T. L., and A. Schalz. 1973. Cytochrome c oxidase from bakers yeast. II Site of translation of the protein components. J. Biol. Chem. 248: 1355-1360.

27. Simon, L. M. and E. D. Robin. 1972. Relative anaerobic glycolytic capacity and pyruvate kinase activity of rabbit tissues. Int. J. Biochem. 3: 329-332.

28. $\mathrm{Wu}, \mathrm{R}$., and E. Racker. 1959. Regulatory mechanisms in carbohydrate metabolism. III Limiting factors in glycolysis of ascites tumor cells. J. Biol. Chem. 234: 10291035.

29. Lowry, O. H., and J. V. Passanneau. 1964. The relationships between substrates and enzymes of glycolysis in brain. J. Biol. Chem. 239: 31-42.

30. Weber, A. 1977. Enzymology of cancer cells. N. Engl. J. Med. 296: 541-551.

31. Simon, L. M., S. G. Axline, B. R. Horn, and E. D. Robin. 1973. Adaptations of energy metabolism in the cultivated macrophage. J. Exp. Med. 138: 1413-1425. 